\title{
The history of tuberculosis: from mummies to multidrug resistance across the Royal Touch
}

\author{
Cristina Morazzoni, Massimo DePaschale \\ Microbiology Operative Unit, Legnano Civil Hospital, Legnano, Italy
}

\section{Summary}

Writing about a complete history of tuberculosis would obviously require more than the space we have available; therefore, this brief manuscript is just aimed to summarize some of the most curious and potentially less known aspects of this long lasting disease that likely started to accompany the mankind from the very beginning and still is among the most worrying illness affecting the poorest classes worldwide.

\section{The history of this illness over time, from Greek to modern Era}

The first evidences of human tuberculosis infection (TBI) was found in a cemetery near Heidelberg, inside some bones from the Neolithic Era showing the typical structure deformation that is frequently observed in cases of spinal TBI (some authors called tuberculosis the very first disease known by humans) (9). Typical signs of this disease were also found in Egypt's mummies dated back in 3000-2400 BC: the most convincing evidence of this extremely old suspected Mycobacterium tuberculosis related disease was found in the mummy of the priest Nesperehen, discovered by Grebart in 1881. This evidence is mainly based on the combination of signs of spinal TBI along with the

Correspondence: Cristina Morazzoni, U.0.C. Microbiologia, Presidio Ospedaliero di Legnano, ASST Ovest Milanese, Via Papa Giovanni Paolo II, 20025 Legnano (MI), Italy.

E-mail: cgmora83@gmail.com

Key words: Tuberculosis; history of mycobacteria infections, Bacillus Calmette and Guerin, Royal Touch.

Contributions: the authors contributed equally.

Conflict of interest: the authors declare no potential conflict of interest.

Received for publication: 28 January 2016.

Accepted for publication: 15 February 2016.

(C) Copyright C. Morazzoni and M. DePaschale, 2016

Licensee PAGEPress, Italy

Microbiologia Medica 2016; 31:5782

doi:10.4081/mm.2016.5782

This article is distributed under the terms of the Creative Commons Attribution Noncommercial License (by-nc 4.0) which permits any noncommercial use, distribution, and reproduction in any medium, provided the original author(s) and source are credited. presence of abscess in the ileo-psoas muscle. Similar patterns of clinical marks resembling TBI were also discovered in other mummies from the older Egypt. It is furthermore very likely that TBI affected other illustrious people at that age like the Pharaoh Akhenaten and his wife Nefertiti: TBI was already perceived as an important pathological condition since some clues indicate that even in $1500 \mathrm{BC}$ there were a kind of hospitals for tuberculosis (9). The first book referring to this infection was the Herodotus' Tales where the Greek historian reported how some Generals from the Persian militia were obliged to leave the campaign against Spartans because of TBI (Book VII, Polimnia). Hippocrates, the father of Western Medicine from the Greek island of Kos, in the first book of his Of the Epidemics compendium (400 BC), described some of the clinical characteristics of TBI: fever, colourless urines, cough producing dense sputum, lack of thirst and appetite. However the great Greek, as many others at that time, believed TBI to be a hereditary illness, with only just a few more illuminated people being against this idea (one of those brighter thinker was Aristotle, which thought it was an infectious disease at least among pig) (1). During the age of the Roman Empire, Pliny the Younger, wrote a letter to Prisco in which he described the symptoms of the infection as he saw in Fannia, a young girl: she suffer from attacks of fever, with a worsening cough over the time, which makes she really emaciated and weak (Pliny the Younger, letter VII, 19). Moving to a completely different location, in South America, the first convincing evidence of TBI could be found in the Arawak culture around $1050 \mathrm{BC}$ and in the so called Paracas-Caverna culture. However, another important discover is related to findings obtained from a mummy of a child (apparently of 8-10 years of age), from the Peruvian site of Hacienda Agua Salada (Nasca culture), dated some $700 \mathrm{BC}$. In this material it has been possible to clearly state the presence of mycobacteria (7). During the Medieval Age, no progress was made about the knowledge of TBI, as expectable, given the cultural darkness that characterized those centuries. The great Arabic physician and philosopher Ibn Sin, best known in the Occidental culture under the name of Avicenna, thought that TBI was an infective and difficult to treat disease: this opinion was shared by the Persian scientist Abu Bakr Muhammad ibn Zakariya al-Razi (also known under his latin name of Rasis) that in the light of being one of the earliest proponent of the experimental medicine, made some criticism to the ancient idea of TBI.

In between the $13^{\text {th }}$ and the $14^{\text {th }}$ centuries, the Catalan alchemist Arnaldo da Villanova elaborated and wrote an etiologic theory for TBI that was strictly linked to the Hippocrates' one: the idea was that the disease was caused by a dropping of cold humor from the head to the lungs that, as a consequence, started to malfunction (11). Interestingly, in those darkness centuries, also the Holy Inquisition took care of TBI related disease: a note from $12^{\text {th }}$ century, in Hungary, contained a long explanation about causes of TBI. This was because one prisoner, that was actually under judgment as a potential heathen, asserted that his illness was caused by a dog-like demon, able to eat his lungs after being entered in the human body (10). The cough showed by this victim of demoniac possession was perceived and identified as the demon's barks: the obvious end of this imaginative and sad story was that when the demon finished to eat the lungs, he just killed the host. 
Along with Christianity's diffusion, the roles played by the monarchs over Europe included more and more the one of magical religious characters provided with therapeutic powers: so it came to actuality to believe that the Royal Touch (the touch of kings, mainly the one from England or France, being these two countries among the most powerful at that time), was able to heal disease thanks to the divine rights attributed to the ruler. As an example, the French King Henry IV usually made the ritual once a week, after taking the Holy Body. The practice of the royal healing was so common in France, that the cutaneous form of TBI localized into the neck was known as le mal du roi (= the king's disease) or king's evil, since the monarch's touch was very often dedicated to these patients. At the beginning, the ceremony of the royal touch was quite informal (8): sick people could ask to the Court to get the king's touch and this bestowed at the first available occasion. However, the fast spreading of TBI among France and England, prompted to a raise in these requests for the Royal Touch and this fact carried to an increased formalism and to a more efficient ceremony: a pamphlet showing the days and times when the king would have been administering the royal touch were regularly made publicly available among the common folk since the era of King Louis XIV in France and this was accompanied by mercifully donation of some money. Even if the true medical value of this ritual is at least doubtful, the ceremony was often perceived by the hoi polloi as a miraculous healing and the members of the regal clique more and more presented the Royal Touch as the best opportunity (if not the only available at that time) to recover from a deadly and spoiling disease. In this frame it is noteworthy what Andrè du Laurens, the elderly doctor of king Henry IV, wrote about the recovery rate following the Royal Touch: at least half of the people who received it ... and this within a few days (5). The Royal Touch was popular until the $18^{\text {th }}$ century, and to get a confirmation about the spread use of this magical practice for TBI it is just enough to check the parish registers of the 0xfordshire, which not only contains registrations of baptisms, marriages and deaths, but also names of people who obtained the Royal Touch. Of course the true value of this ritual for TBI is far from being confirmed and proven.

The first hypothesis about the microbial etiology of TBI was made by Girolamo Fracastoro, in his book De contagione et contagiosis morbis et curatione, libri tres, (published in Venice in 1546), where the scientist from Verona made the theoretical assumption that TBI was transmitted by an invisible virus. His theory included the possibility for this virus to survive for one or two years on dresses of infected people and that the transmission occurred by direct contact or via a close interaction with fluids spread by a sick person (called fomes) ... that's not so far away from what we know nowadays about the diffusion of tubercular mycobacteria. Another relevant observation made by Fracastoro, was about the transmissibility of the disease without an interpersonal direct contact, but this remained, quite obviously, given the level of knowledge about germs available to the scientists in the $15^{\text {th }}$ century, totally unexplained (11). The Swiss scientist Philippus Aureolus Theophrastus Bombastus von Hohenheim (also know as Paracelsus), more or less in the same period when Fracastoro made the above hypothesis, supported instead the idea that the disease we today know related to TBI was caused by a dysfunction of a selected internal organ: whenever this was involving the lungs, thus developing a kind of a rock inside this organ by a process he defined tartaric, the disease became evident. About one century later, the Dutch scientist Franciscus de le Boë Sylvius distinguished among different clinical and anatomical types of tuberculosis (so identifying the lungs and gangliar types) and was the first one to recognize that the skin lesions caused by the scrofula were similar to the tubercles observed in the lung from patients with phthisis: in his book Opera Medica, published posthumous in 1679, is clearly written that phthisis is the scrofula of lungs (4).

Thomas Willis, a British physician, more famous for his Cerebri Anatome that describes many physiological and pathological features of the central nervous system, such as the vascular district known as the Circle of Willis, more or less contemporarily, concluded that all the lungs diseases leads, as a clinical effect, to the typical weakness shown during tuberculosis (12). Willis, at that time, did not know the true nature of this illness but he thought (in the books entitled De Fermentatione and De Febribus) it was caused either by sugar degradation or due to the acidification of blood.

Richard Morton, a British scientist who was trained at the Magdalen Hall college in Oxford in the $17^{\text {th }}$ century, in 1689 , published his opera Phtisiologia, seu exercitationes de phtisi tribus libris comprehensae, where he defined that the presence of tubercles was a conserved feature of lung TBI. During this time the illness was so commonly spread that Morton said I've never seen anyone died without been touched by tuberculosis, at least among those died after puberty.

Some 30 years later, in 1720, Benjamin Marten, in his A new theory of consumptions more especially of phthisis or consumption of the lungs proposed that this illness was caused by wonderfully minute living creatures resembling the idea of the Animalcula, microscopic living beings, capable to survive in the body of a host (as the ones described by Anton van Leeuwenhoek in 1695) (3). This model remained not confirmed and it took some 160 years until Robert Koch demonstrate the correctness of this theory, showing the correlation between phthisis and Mycobacterium tuberculosis. Less than 50 years after the work of Marten, in 1768, the Scottish Robert Whytt made the first clinical description of tubercular meningitis (13) and in 1779, Percival Pott, an English surgeon, described the vertebral lesions present in bone $M$. tuberculosis infection that is still named after him.

In 1761, Joseph Leopold Auenbrugger, an Austrian doctor, developed the back percussion's method for the diagnosis of lung TB, a method that was prosed again by the French physician Jean-Nicolas Corvisart in 1797. After having found this method useful in the clinical practice, Corvisart made it available (after a translation into the French language) to the academic community. In the meantime the British medical pioneer William Stark (he died at the age of 29 by self experiment on himself more than 20 restrictive diets until a fatal form of scurvy developed) proposed the tubercles observed in the different type of TB to evolve as skin wounds or parenchymal cavities, since he believed (quite correctly) that the diverse types of TBI were just dissimilar ways of evolution of the same illness (6). Johann Lukas Schönlein (well know for the so called Henoch-Schönlein purpura) was professor of medicine in Wurzburg, Zurich and Berlin, (where he served as a physician for the King Friedrich Wilhelm IV of Prussia). In his Sistematik de speziellen pathologie und therapie proposed to use the word tuberculosis to describe the tubercles illness. In London, at the end of $18^{\text {th }}$ century, the mortality related to TB was about 1 on 7 death, and since 1750 this rate increase to 1 on 5.25 and up to 1 on 4.2 at the end of the century. The Industrial Revolution, thanks to the poverty and poor hygienic conditions, contributed greatly to the development of the ideal conditions for the diffusion of the illness. During the $19^{\text {th }}$ century TB was also called with a series or very efficacious definitions such as the White Plague, the pain of living and the disease of the century. At that time TBI was also seen as a kind of romantic illness, because people thought TBI itself provided the affected people with a sort of hidden increased sensibility to art and romance. The slow progression of the infection permitted anyway a good death, thus leaving enough time to its victims to take care of their business before dying: TB has never been an acute and fast killing disease. The illness was also associated with an image of spiritual purity, thus leading many young (in particular belonging to the upper and noble classes) girls to use a kind of make up on their face to appear paler and sick, thus resembling the visage of TB infected women. The English poet Lord George Gordon Byron wrote in 1828 the following sentence: I would like to die of tuberculosis, and this greatly contributed to raise the concept of TB as an artists' disease. In the early $19^{\text {th }}$ century, TB make an illustrious victim: RenéThéophile-Hyacinthe Laennec, the French physician who invented the stethoscope died at the age of 45 and it is said that his nephew Mériadec Laennec, diagnosed the disease by using the just invented device. The contagion was likely acquired by Laennec senior while assisting patients and studying samples from died TB sick persons.

In 1869, the French Jean Antoine Villemin demonstrated for the very first time the infective nature of tuberculosis. He inoculated some mate- 
rial obtained from infected humans into laboratory rabbits that subsequently developed the infection. This experiment was the first evidence that TB was a transmissible disease even if the true vehicle of transmission was still totally obscure: this theory received a large agreement among the members of the scientific community. Less than 15 years later, in 1882, a Prussian doctor called Robert Koch, applied a new staining method on a sputum sample obtained from a patient suffering from TBI: this was the first demonstration of the causal agent of TB, the bacillus of Koch (M.tuberculosis). When Koch started his work, he was already aware of the experimental transmission of TB achieved by Villemin and others scientists who performed again these works, like Julius Conheim (formerly a student of Virchow). Robert Koch had access to the phthisis ward of the Charitè Hospital in Berlin where he worked on anthrax before being involved in TB research: the final outcome of Koch's work on anthrax was the discovery of its causal agent, Bacillus anthracis.

During his early time in research, Robert Koch became a friend of Ferdinand Cohn, who is right considered among the founding fathers of modern microbiology. At that time Cohn was serving as Director for the Botanical Institute at the University of Breslau: the relationship between Koch and Cohn brought to a common development of innovative methods in bacteriology. On August $18^{\text {th }} 1881$, while staining a sputum sample with methylene blue, Koch observed rectangular structures that he cannot distinguish from an unspecific staining artefact. Being a bright minded man, he tried to increase the contrast of the staining by adding some Bismarck brown that stains acid mucins to yellow colour and so the structures became bright and more transparent. He continuously tried to improve the technique by experimenting different concentrations of alkalis in the solution and at the end he found the best combination of strainers and moisture, making the bacilli well observable. Following this first result, Koch continued his attempt to grow the microbes and at the end he succeeded to develop bacteria in a medium based on blood coagulated serum incubated at $37^{\circ} \mathrm{C}$. The last step toward the final achievement of the etiologic relationship between these microbes and tuberculosis was the inoculation of rabbits with this preparation. This resulted in the animals to die with clear symptoms of tuberculosis: the Koch's postulates were more or less established. On March $24^{\text {th }} 1882$, Koch showed the full set of results so far obtained in a conference entitled Uber Tuberculose at the Phisiology Society of Berlin. The publication followed some 3 weeks later and since more that 130 years March $24^{\text {th }}$ become the World day of Tuberculosis. The paper Die Äetiologie der Tuberkulose, that was linking the newly discovered mycobacterium with all the clinical manifestations of tuberculosis, appeared on April $20^{\text {th }} 1882$ in the Berliner Klinischhen Wochenschrift. In 1890 he also developed the tuberculin, a purified protein derived from mycobacteria, which in 1908 was used by Charles Mantoux as the base of the first intradermal test for the diagnosis of TBI. In his paper of 1882 Koch's wrote a famous sentence: If the importance of a disease for mankind is measured from the number of fatalities which are due to it, then tuberculosis must be considered much more important than those most feared infectious diseases, plague, cholera, and the like. Statistics have shown that 1 in 7 of all humans die of tuberculosis. It was thank to the studies of the Italian scientist Edoardo Maragliano that in the first decade of 1900 the first vaccine against tuberculosis was made available. This was prepared with heat-inactivated mycobacteria and unfortunately the efficacy was not complete. In the groove dug by Maragliano, the seeds of further scientific developments for the control of tuberculosis quite soon germinated, thanks to the work of two other Italian scientists: Giovanni Petragnani and Gaetano Salvioli. Again the vaccines invented by these Italians showed an incomplete protection against TB and their clinical use was almost abandoned in the early 70's of 1900 .

A different approach to the development of a vaccine for TB was followed by the French Albert Calmette and Camille Guérin (working together at the Institut Pasteur in Lille) that between 1908 and 1921 started to evaluate a preparation obtained from bovine mycobacteria. The virulence of these germs was mitigated over a period of 13 years by passaging the mycobacteria more that 230 times in a medium containing bile, potatoes and glycerin. This long lasting process prompted to the establishment of a non-virulent strain variant of mycobacterium named $B C G$ (Calmette-Guerin's Bacillus) after the names of the two scientists.

he use of BCG as human vaccine was started in France in 1921. The League of Nations adopted the BCG as a tool to prevent TB in 1929 but this was not widely accepted. Only after the $2^{\text {nd }}$ Word War the BCG was extensively used in Europe in the frame of the International Tuberculosis Campaign. Unfortunately the protection achieved, following the BCG vaccination, has been shown to last for a limited time: with a few exceptions (like the one represented by the Native American populations) the immunity is no more protective after 20 years from the vaccination. Interestingly the BCG has been demonstrating to achieve a $26 \%$ protection against other human mycobacteria related disease such as leprosy.

The widely perceived hope to completely eradicate TBI was crushed down in 1980 when a drug-resistant strain of mycobacterium began to spread around the world. Only in New York this epidemic became a truly new emergency with some 20,000 cases of TBI caused by multidrugresistant mycobacteria. The germs were resistant to both rifampicin and isoniazid so raising an issue for the treatment of these infections. Also as an answer to this growing emergency, the World Health Organization declared a new global state of emergency in 1993 in order to allow all the member States to allocate resources to fight against this old but still present and diffuse disease. The rest of this story is just true and the all days' experience of microbiologists worldwide.

\section{References}

1. Aristotele. History of animals, book VIII. 350 B.C.

2. Bonah $\mathrm{C}$. The experimental stable of the BCG vaccine: safety, efficacy, proof, and standards, 1921-1933. Stud Hist Philos Biol Biomed Sci 2005;36:696-721.

3. Daniel TM, ed. Pioneers of medicine and their impact on tuberculosis. Rochester: Boydell \& Brewer; 2000.

4. Debus GA. Chemistry and medical debate. Van Helmont to Boerhaave. London: Science History Publications; 2001.

5. Du Laurens A. In: Discours de la conservation de la veuë: des maladies melancoliques: des catarrhes, \& de la vieillesse. Paris: Jamet Mettayer, 1597.

6. Dubos J, Dubos R. The white plague: tuberculosis, man and society. $2^{\text {nd }}$ ed. New Brunswick: Rutgers University Press; 1987.

7. Gómez i Prat J, de Souza SM. Prehistoric tuberculosis in America: adding comments to a literature review. Mem Inst Oswaldo Cruz 2003;98:151-9.

8. Mitchinson J, Oldfield M. QI: quite interesting facts about Kings. The Telegraph. 9 January 2009. Available from: http://www.telegraph.co. uk/men/the-filter/qi/4176490/QI-Quite-interesting-facts-aboutKings.html

9. Monir Madkour M, ed. Tuberculosis. Berlin - Heidelberg: Springer Verlag; 2004.

10. Radloff W. Nachtrage zum Chuastuanit (Chuastuanvt), dem Bussgebete der Manichaer (Hoerer). Bulletin de l'Academie Des Sciences de St. Péterbourg 1911:5:867-96.

11. Tortoli E, Piersimoni C, Scarparo C, et al. Micobatteriologia clinica. $2^{\text {nd }}$ ed. Pavia: CEA Selecta Medica; 2013.

12. Waksman SA, ed. The conquest of tuberculosis. Berkeley-Los Angeles: University of California Press; 1964.

13. Whytt R, ed. Observations on the dropsy in the brain. Edinburgh: Balfour, Auld \& Smellie; 1768. 